\title{
ENHANCEMENT OF INTERACTION BETWEEN INFILLED WALL AND RC FRAMED STRUCTURE
}

\author{
P.Jagadeesan ${ }^{1}$ \\ ${ }^{\text {I}}$ Professor, Department of Civil Engineering, Guru Nanak Institutions Technical Campus, Ibrahimpatnam, \\ R.R.District, Telangana, India
}

\begin{abstract}
Normally, Reinforced Concrete (RC) framed structures are formed through structural and non structural elements and structural elements are designed in RC framed structure. Non structural element likes infilled wall is not designed but it is used to fill the openings and separation of room in buildings. However, some percentage of behaviour between infill and frame can take itself at the time of loading. According to that, the aim of the project is to improve interaction between RC frame and infilled wall. In this project, three types of specimen were prepared for studying the influence of infilled wall in framed structure by through single bay, single storey specimen with one-tenth scale model as RC framed structure without infilled wall, RC framed structure with infilled wall, RC framed structure with infilled wall under strengthened by connector. Here, properties of concrete and steel were also measured for analysis of experimental work. Besides, the specimens were prepared under earthquake detailing and testing of specimens was carried out through the Universal Testing Machine. Experimental values are compared in the order of strength, ductility and failure mechanism of the specimens. Finally, the ultimate load carrying capacity of RC frame with connector is 1.633 times greater than that of RC frame without infilled wall. The initial stiffness of the RC frame with connector was 1.131 times higher than that of the frame without infill. The ductility of frame with infilled wall is 4.44 times greater than that of frame with infilled wall.
\end{abstract}

Keywords: Infilled wall, stiffener, ductility, stiffness

\section{INTRODUCTION}

Reinforced concrete frame building with masonry infill walls has been widely constructed for commercial, industrial and multi-family residential uses in seismic-prone regions worldwide. Masonry infill typically consists of brick, clay tile or concrete block walls, constructed between columns to beams of a RC frame. Masonry infill walls can be found as interior partitions or exterior partitions or erection facades in reinforced concrete and steel frame structures. Masonry infill walls are found in most existing concrete frame building systems. Infilled frame designates a composite structure formed by one or more infill panels surrounded by frame, the frame is built first and then infilled with one or more masonry panels. Kai Qian and Bing Li[1] studied cause of masonry infill wall on the importance of RC frames to against progressive collapse and proved that experimental and analytical results indicated that ignoring the effects of masonry infill walls to resist progressive collapse of load carrying capacity, initial stiffness and load resisting mechanisms. Also, the suitability and effectiveness of fiberreinforced polymers (FRP) in strengthening and/or repairing unreinforced masonry infill walls in reinforced concrete frames which are subjected to in-plane seismic/cyclic loading were investigated by Tarek and Yousef[4]. Particularly in multi-storey buildings, the loads are occurring as vertical loads and do not pose much of a problems, but the lateral loads due to wind or earthquake tremors are a matter of great concerned need special characteristics in the design of buildings. Although, the infill panels significantly enhance both the stiffness and strength of the frame, their contribution is often taken into account because of the lack of knowledge of the composite behaviour of the frame and the infill. Yong[6] presented a comparative study of the nonlinear behaviour of reinforced concrete RC frame multi-storey structures which was carried out on the basis of measured response of four, six-storey, three-bay framed structures, namely a regular bare frame, a discontinuous-column frame, a partially masonry-infilled frame and a wall-frame system. For the wall-frame system, an adequate counter measure against rocking of the $\mathrm{RC}$ wall was shown to be a key to maintaining the effectiveness of the system at advanced inelastic response. Besdies, Patnala and Ramancharla[2] attempted the non-linear behaviour of unreinforced masonry infill frames with varying storey using applied element method. One, two and three storey frames with and without openings were analysed and, drift ratio and strength of frame were also observed. The presence of this non-structural masonry infill walls can affect the seismic behaviour of framed building to large extent. These effects are generally positive in masonry infill walls can increase global stiffness and strength of the structure. On the other hand, potentially negative effects may occur such as torsional effects induced by in planeirregularities, soft storey effects induced by irregularities and short column effects. It has been generally recognized that infill frame structure exhibit poor seismic performance, since numerous buildings have failed in past earthquakes. The infill frames have greater strength as compared to 
frames without infill walls. The presence of the infill walls increases the lateral stiffness considerably. Recent earthquakes showed that infill walls have an important effect on the resistance and stiffness of building. Wei-Wen et.al.,[5] also performed the out-of-plane seismic behaviour of reinforced concrete (RC) frames infilled with brick walls. Five full-scale specimens were tested. The test results showed that the contribution of the brick walls to the out-ofplane lateral strength of frames was not straightforward, although the residual strength of frames infilled with brick walls was clear. Retrofitting of specimens enhanced the peak lateral strength and residual strength in tested specimens. The proposed analytical model satisfactorily predicted the load-displacement relationship of all specimens. However, the effect of the infill walls on the building response under seismic loading is very complex. Full scale experiments test are best option for better understanding of the behaviour of infill frames. But full scale experimental test are too expensive, so experimental studies in reduced scale specimens are tested. Ricardo[3] study was based on the equivalent strut approach (simplified model), a damage model was proposed in this paper for the characterization of masonry walls subjected to lateral cyclic loads. The model developed along the lines of the continuum damage mechanics, has the advantage of including explicitly the coupling between damage and mechanical behaviour and so it is consistent with the definition of damage as a phenomenon with mechanical consequences. An evaluation of the structural performance of the analysed masonry infilled frames has been performed based on the calculated damage values and the storey drifts. From the literature review, it was observed that interaction of infilled wall and RC framed structure is necessary for development of research activities.

\section{OBJECTIVE OF RESEARCH PROGRAMME}

The objective of research work is to improve the infilled RC framed structure by enhancing the interaction of infilled wall and RC framed elements using steel connector under single bay, single storey infilled RC framed structure with one-tenth scale model. Three specimens were cast such as $\mathrm{RC}$ frame without infilled wall, RC frame with infilled wall and $\mathrm{RC}$ frame with infilled wall under connector. The test results showed that ultimate load carrying capacity, initial stiffness, ductility and failure of mechanism of specimens.

\section{MATERIAL SPECIFICATION}

The behaviour of RC frames with and without masonry infilled wall are subjected to diagonal loading were studied through an experiment programme. Cement, fine aggregate, coarse aggregate and bricks were used to make infilled RC framed structure. Initially, the quality of materials was observed through as M20 concrete and it was designed with mix proportions of 1:1.34:3.17 with 0.5 water-cement ratio. Finally, the compressive strength and split tensile strength of M20 concrete was observed as $31.41 \mathrm{~N} / \mathrm{mm}^{2}$ and 1.41 $\mathrm{N} / \mathrm{mm}^{2}$ respectively. Fe415 grade of steel was also used as reinforcement in these specimens. Chamber brick were used for constructing masonry work. This brick were modeled as per scale size as $6.6 \mathrm{~cm} \times 3 \mathrm{~cm} \times 3 \mathrm{~cm}$. Here, three types of specimens were prepared to evaluate the interaction of infilled RC framed structure and details of specimens are shown in table 1 .

Table-1: Details of Specimens

\begin{tabular}{|l|l|l|l|l|}
\hline \multirow{2}{*}{ Sl. No. } & \multirow{2}{*}{ Frame Designation } & \multicolumn{2}{|l|}{ C/S Dimensions in mm } & Main \\
\cline { 3 - 6 } & & Beinforcement \\
\hline 1 & RC frame without infilled wall & 50 & 60 & 4 Nos, 6mm $\phi$ \\
\hline 2 & RC frame with Infilled wall & 50 & 60 & 4 Nos,6 mm $\phi$ \\
\hline 3 & RC frame with Infilled wall strengthened under connector & 50 & 60 & 4 Nos, 6mm $\phi$ \\
\hline Shear reinforcement: 4 mm $\phi @ 2$ legged vertical stirrup & & \\
\hline
\end{tabular}

A wood mould specially made for the preparation of specimens. The arrangement of the mould is shown in figure 1. Each portion of mould is separate part and using bolt joint can easily form it. The diagonal loading is provided with an extension. The main reinforcement used for all the specimens was HYSD steel bars of $6 \mathrm{~mm}$ diameter. The stirrups were used as plain mild steel bars of $4 \mathrm{~mm}$ diameter. The loading diagonals were provided by steel plate and arrangement of reinforcement is shown in figure 2 . 


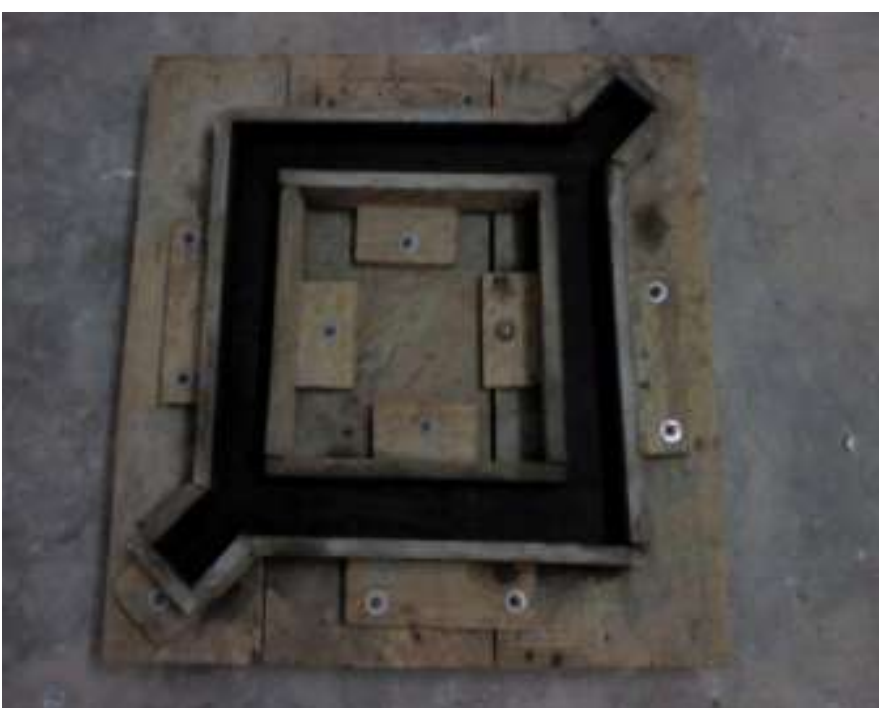

Fig-1: Mould for specimen

\section{EXPERIMENTAL SETUP}

All these three RC frames were cast and tested after 28 days of curing. The specimens were subjected static loading under the Universal Testing Machine (UTM) and dial gauge were provided to measure the deflection of specimens. Here, the loading is given in the diagonal form of specimen. The loading arrangement of specimen is shown in figure 3 . The specimens were loaded upto the failure stage and at every 5 $\mathrm{kN}$ load, the deflection was observed.

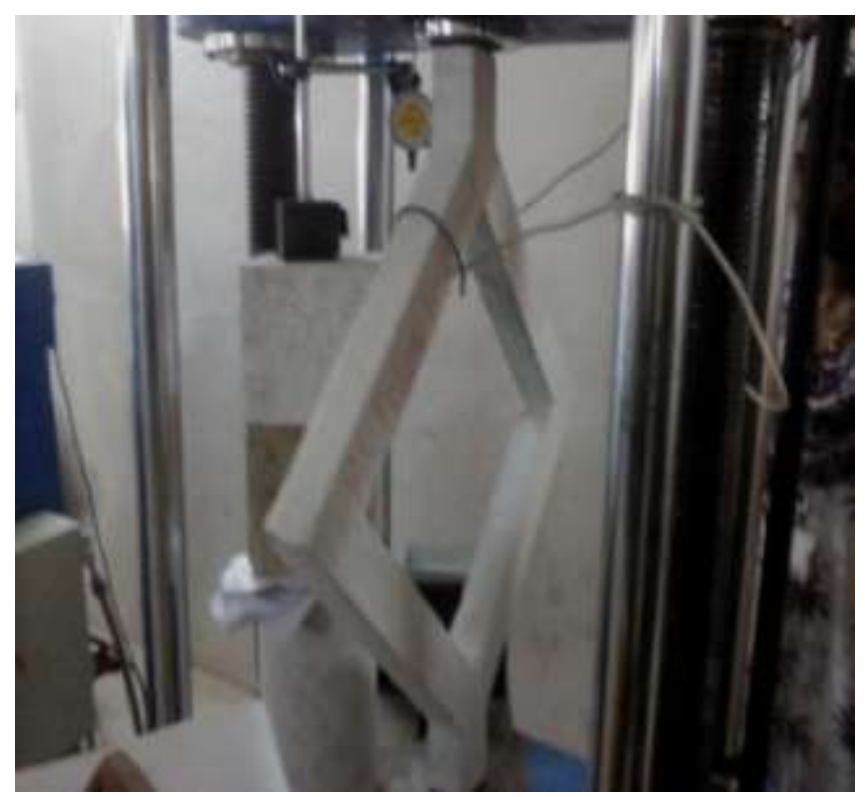

Fig-3: Loading setup of specimen

\section{EXPERIMENTAL INVESTIGATION}

\subsection{General}

In this investigation, three types of specimens were studied such as RC frame without infilled wall, RC frame with infilled wall, $\mathrm{RC}$ frame with infilled wall under strengthening by connector. The geometry of cross section

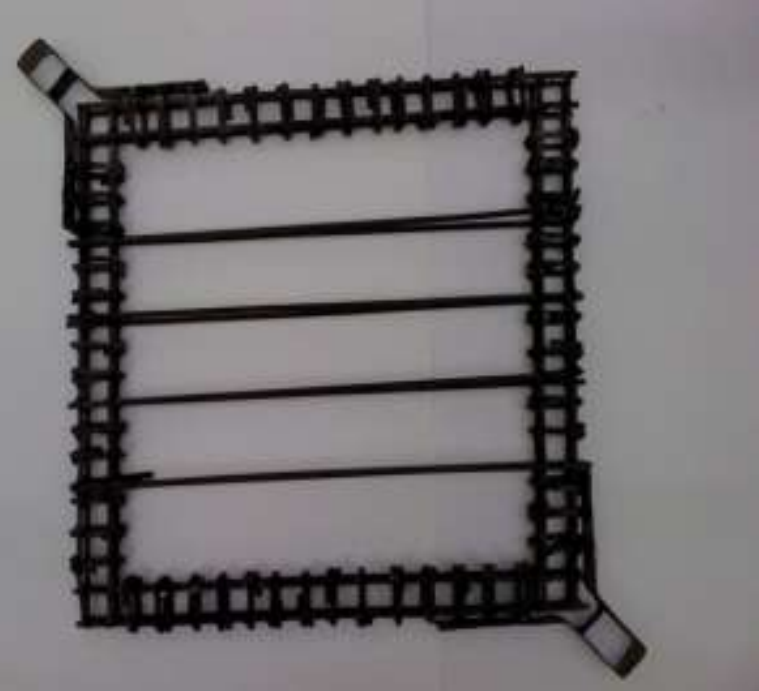

Fig-2: Reinforcement details of specimen

of RC frame and infilled wall is constant for all the specimens. The behaviour of each different specimen was tested and that results are discussed below.

\subsection{Behaviour of RC Frame without Infill}

Figure 4 shows the behaviour of load Vs. deflection of RC frame without infilled wall. Here, RC frame was subjected to static loading through UTM, yield load and ultimate load was observed as $21 \mathrm{kN}$ and $27.85 \mathrm{kN}$ respectively. The first crack was found at the joining of beam-column joints, after that crack was prolongated in the specimen, finally ultimate load is reached. At this ultimate load stage, the maximum deflection was also measured at specimens. The failure pattern of RC frame without brick masonry structure is shown in figure 5 after ultimate load.

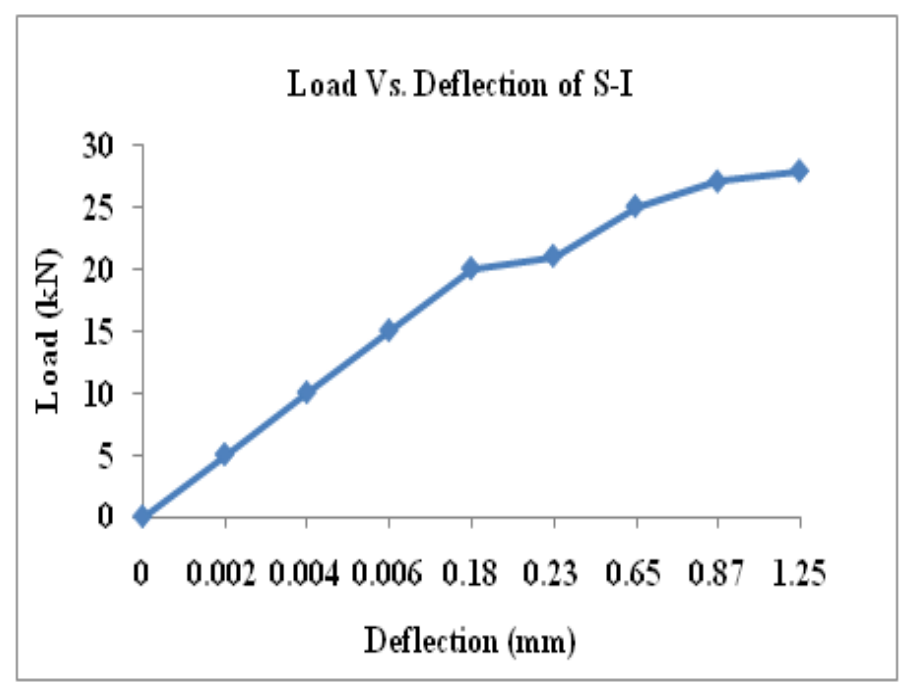

Fig-4: RC frame without infilled wall 


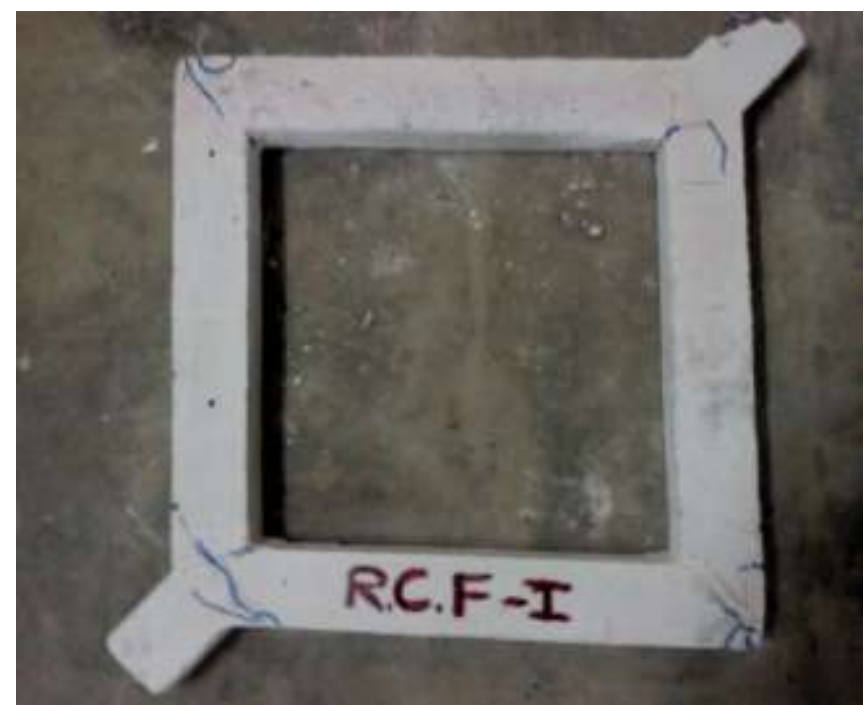

Fig-5: Failure pattern of RC frame without infill

\subsection{Behaviour of RC Framed with Infilled Wall}

The behaviour of infill frame was studied by testing RC frame with ordinary masonry with constant infill thickness and panel size. The first crack was observed in the infill at a load level of $26 \mathrm{kN}$. This crack occurs along diagonal side of infill. The RC frame also cracked along loaded diagonal simultaneously with the cracking of the infill at the load level of $26 \mathrm{kN}$. After the formation of crack in the RC frame, ultimate load reached. At this ultimate load stage,

\section{Load Vs Deflection for RCF - II}

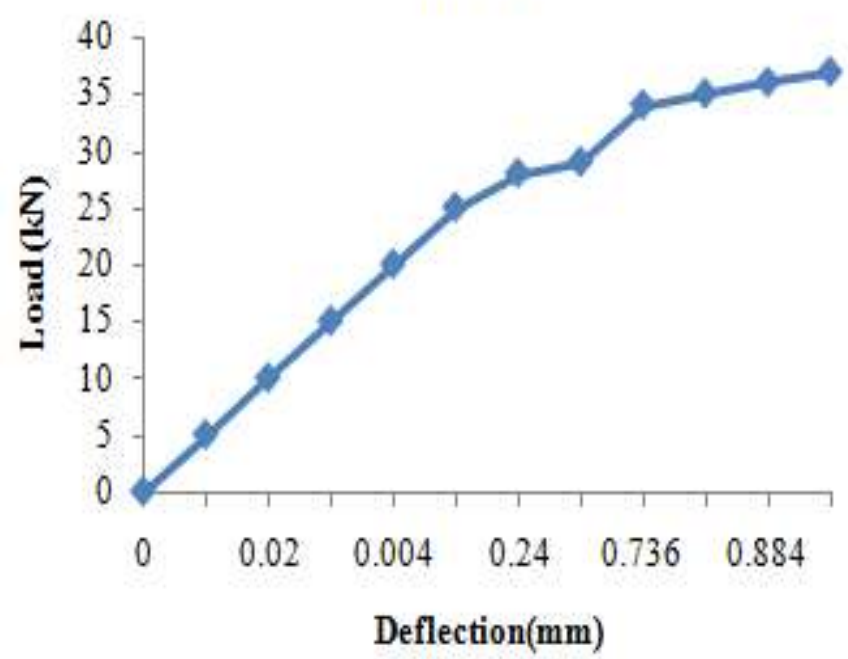

Fig-6: RC frame with infilled wall diagonal tensile crack was observed nearer to the loading point and extended as shear cracks at the support point. The crack was observed in the infill at an ultimate load level of $36.9 \mathrm{kN}$. The load Vs. deflection curves of this specimen is plotted and as shown in figure 6 . The failure pattern of ordinary brick work in $\mathrm{RC}$ framed structure is shown in figure 7 .

\subsection{Behaviour of RC Frame with Infill under Strengthening by Connector}

The load Vs. deflection behaviour of RC frame with infilled wall of this specimen as shown in figure 8. The first crack was observed in the infill at a load level of $31 \mathrm{kN}$. This crack occurs between frame and infill. Diagonal tensile crack was observed nearer to the loading point and extended as shear cracks at the support point. The frame also cracked along loaded diagonal simultaneously with the cracking of the infill at the load level of $31 \mathrm{kN}$. After the formation of crack in the frame, ultimate load is reached. At this ultimate load stage, the crack was observed in the infill at an ultimate load level of $45.5 \mathrm{kN}$. The failure pattern of RC frame with infill under strengthening by connector is shown in figure 9 .

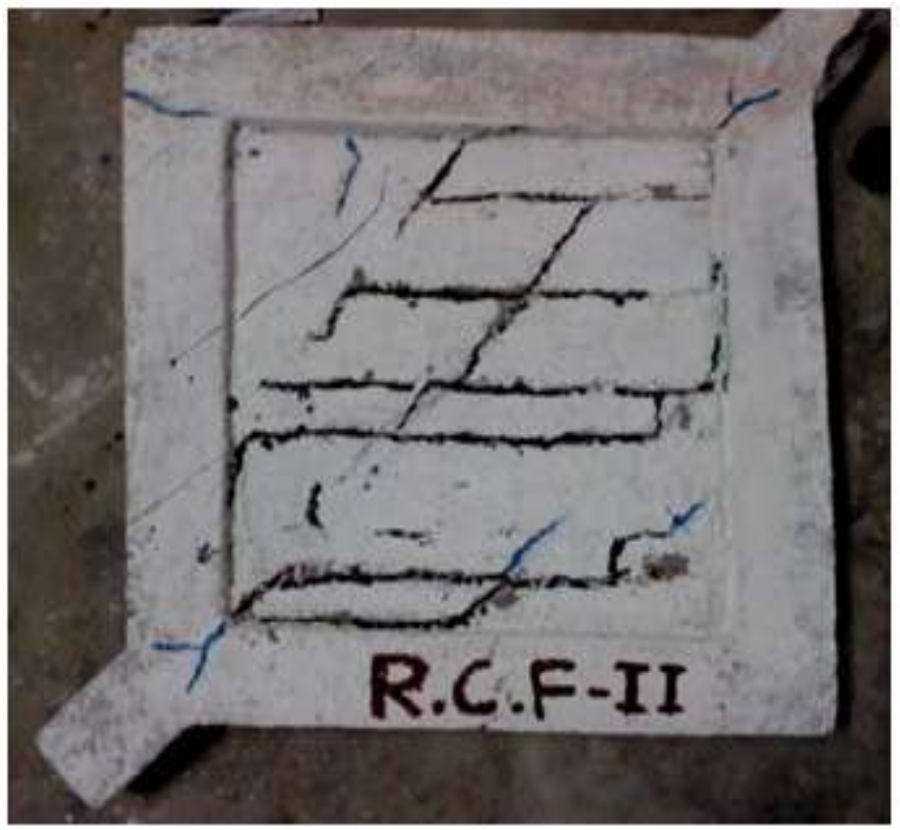

Fig-7: Failure pattern of RC frame with infill 


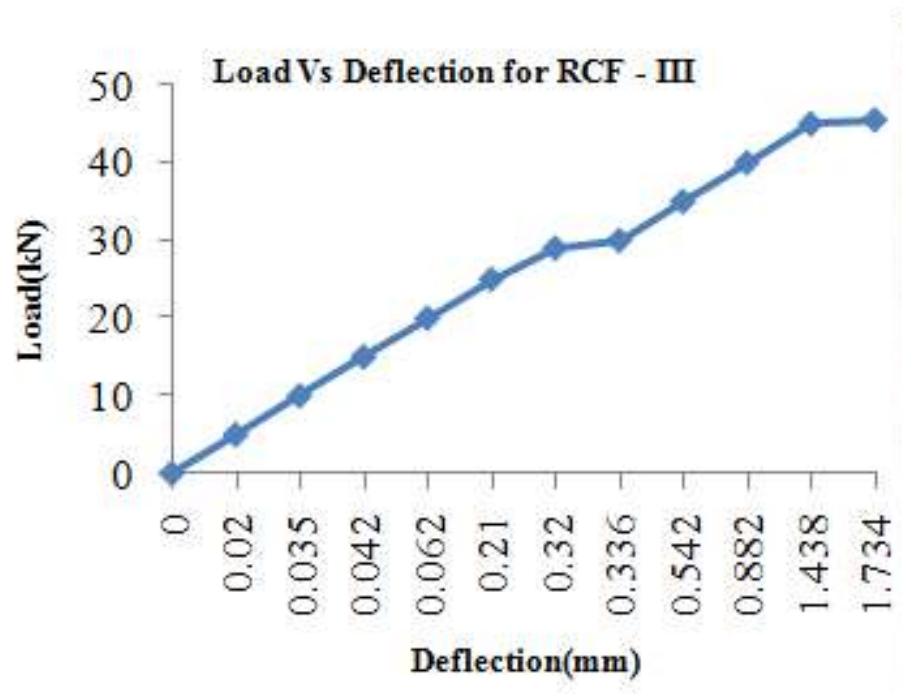

Fig-8: Infilled wall RC frame with connector

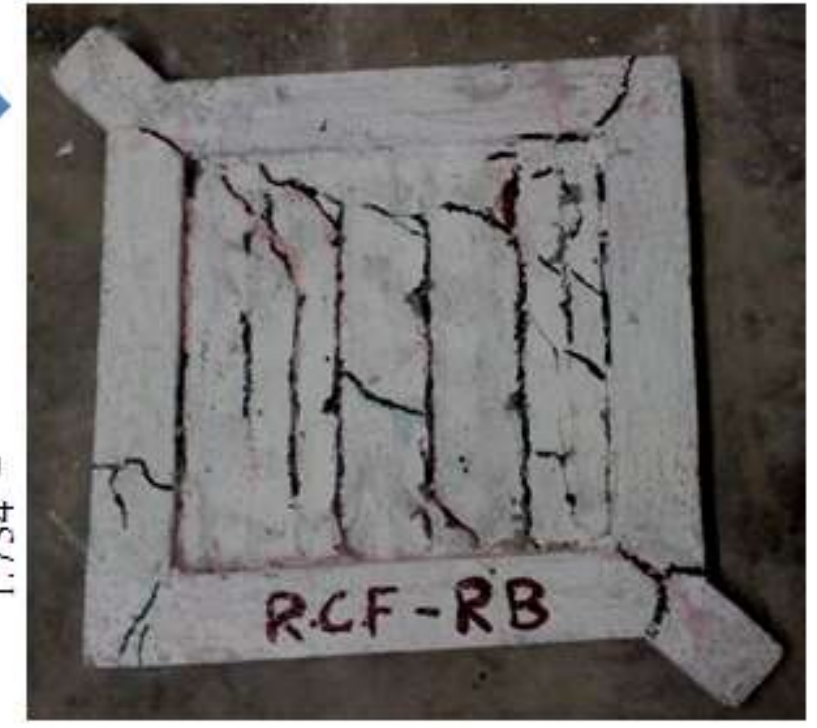

Fig-9: Failure pattern of frame with connector

\subsection{Deflection}

The deflection with respect to maximum load of each three frames such as RC frame without infill, RC frame with infill, RC frame with infill under connector are shown in the figure 10. The deflection of strengthened frame with infill is 1.97 times higher than frame with infill. The deflection of frame with infill under connector is 1.38 times higher than frame without infill.

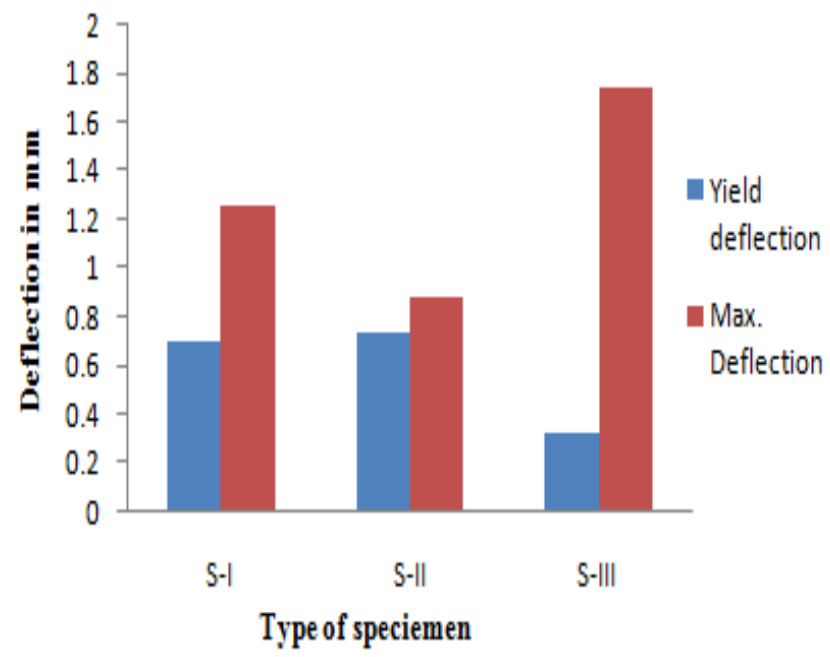

Fig-10: Comparison of yield deflection and ultimate deflection

\subsection{Stiffness Degradation}

Stiffness is defined as the load required causing unit deflection of specimens. The initial stiffness of RC frame without infill is $0.91 \mathrm{kN} / \mathrm{mm}$. The initial stiffness of $\mathrm{RC}$ frame with infill is $0.92 \mathrm{kN} / \mathrm{mm}$. The initial stiffness of strengthened infilled RC frame is $1.03 \mathrm{kN} / \mathrm{mm}$. The stiffness of the RC frame with infill under connector is much greater than that of the RC frame with infill. The comparisons of the stiffness degradations of the RC frames with infill are shown in figure 11 .

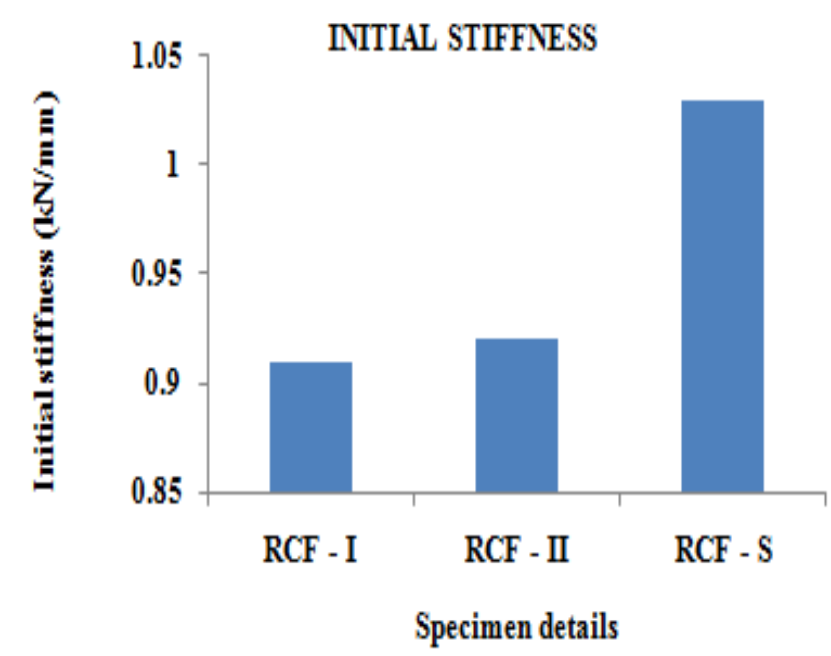

Fig-11: Comparison of stiffness of specimens

\subsection{Ductility Factor}

The ductility factor of the test model is defined as the ratio of the maximum deflection to the yield deflection. The comparisons of ductility of these specimens are shown in figure 12. The ductility for RC frame without infill, RC frame with infill and strengthened infilled $\mathrm{RC}$ frame was 1.78, 1.18 and 5.25 respectively. The ductility of strengthened infilled RC frame is 4.44 times greater than that of RC frame with infill. The ductility of strengthened infilled RC frame is 2.94 times greater than that of frame without infill. 


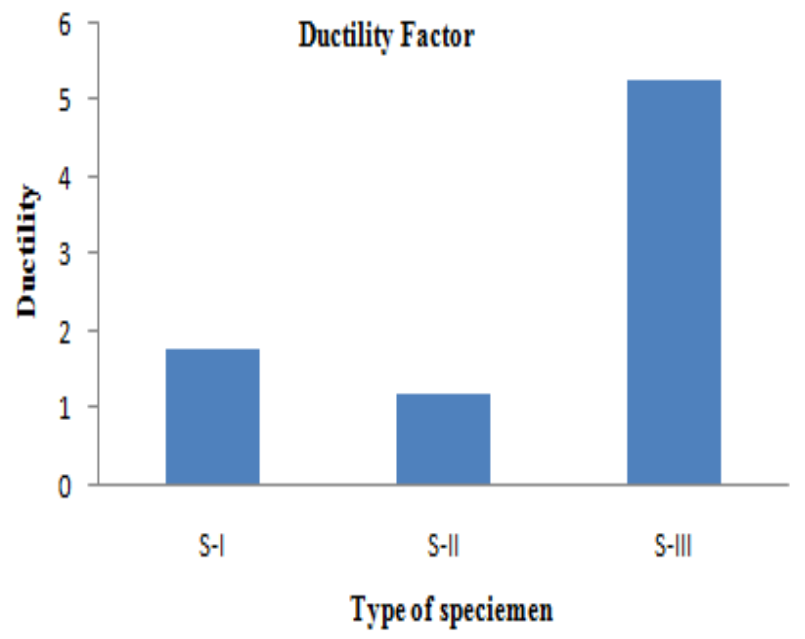

Fig-12: Comparison of ductility

\section{CONCLUSION}

The conclusion drawn based on the experimental investigation on one-tenth model scale of comparative behaviour of RC frame with infilled under static diagonal loading are discussed below.

- The ultimate load carrying capacity of RC frame with infill is 1.32 times greater than that $\mathrm{RC}$ frame without infill.

- The ultimate load carrying capacity of RC frame with connector is 1.63 times greater than that of $\mathrm{RC}$ frame without infill

- The initial stiffness of the frame with connector is 1.131 times higher than that of the RC frame without infill.

- The ductility of strengthened infilled RC frame is 4.44 times greater than that of frame with infill.

- The ductility of frame with connector is 2.94 times greater than that of frame without infill.

- Comparing the failure pattern, with infill is sudden falling due to bedding joint failure but with stiffener was failed due to the static diagonal loading and it prevent sudden falling of debris.

\section{REFERENCES}

[1] Kai Qian, \& Bing Li 2017, 'Effect of masonry infill wall on the performance of $\mathrm{RC}$ frames to resist progressive collapse', Journal of Structural Engineering, Vol. 143, no. 9.

[2] Patnala V S Neelima \& Ramancharla Pradeep Kumar 2014, 'Seismic behaviour of RC frame with URM infill: A case study', International Journal of Education and Applied Research, vol. 4, no. 2, pp. 20-26.

[3] Ricardo Perera 2005, 'Performance evaluation of masonry-infilled RC frames under cyclic loading based on damage mechanics', Engineering Structures, vol. 27, pp. 1278-1288.

[4] Tarek H Almusallam \& Yousef A Al-Salloum 2007, 'Behaviour of FRP strengthened infill walls under in- plane seismic loading', Journal of Composites for Construction, vol. 11, no. 3, pp. 308-318.

[5] Wei-Wen Chen, Yeong-Kae Yeh, Shyh-Jiann Hwang, Ching-Hsien Lu \& Cheng-Cheng Chen 2011, 'Outof-plane seismic behaviour and CFRP retrofitting of $\mathrm{RC}$ frames infilled with brick walls', Engineering Structures, vol. 34, pp. 213-224.

[6] Yong $\mathrm{Lu} \mathrm{2002,} \mathrm{'Comparative} \mathrm{study} \mathrm{of} \mathrm{seismic}$ behaviour of multistory reinforced concrete framed structures', Journal of Structural Engineering, vol. 128 , no. 2 , pp. 169-178.

\section{BIOGRAPHIE}

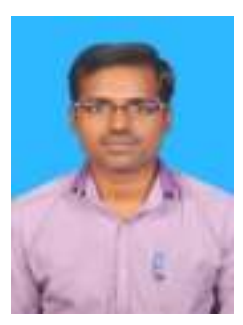

Prof P.Jagadeesan is currently Professor in the Department of Civil Engineering at Guru Nanak Institution Technical Campus, Hyderabad. He completed Ph.D. in strengthening of infilled wall in $\mathrm{RC}$ framed structure. His area of interest includes research on design of concrete structures, nonlinear behaviour and brick masonry. He is a member of Indian Society of Technical Education. 